\begin{tabular}{|l|l|l|l|l|} 
Share: Social Work Jurnal & VOLUME: 9 & NOMOR: 1 & HALAMAN: $66-74$ & $\begin{array}{c}\text { ISSN:2339 }-0042(p) \\
\text { ISSN: } 2528-1577(e) \\
\text { Doi: } 10.24198 / \text { share.v8i1.18100 }\end{array}$ \\
\hline
\end{tabular}

\title{
PENGETAHUAN DAN KESADARAN MASYARAKAT MENGENAI PEMENUHAN HAK ANAK DENGAN DISABILITAS DI KABUPATEN BANDUNG BARAT
}

\author{
${ }^{1}$ Risna Resnawaty, ${ }^{2}$ Rudi Saprudi Darwis, ${ }^{3}$ Agus Wahyudi Riana \\ 1,2,3 Departemen Kesejahteraan Sosial Fisip Unpad \\ ${ }^{1}$ risna.resnawaty@unpad.ac.id, ${ }^{2}$ rsdarwis@yahoo.com.au, 3aguswr@unpad.ac.id
}

\begin{abstract}
ABSTRAK
Artikel ini merupakan hasil penelitian dari mengenai Pengetahuan masyarakat mengenai Hak Anak dengan Disabilitas (AdD) dan Kesadaran masyarakat untuk turut membantu orang tua AdD dalam mengenai pemenuhan kebutuhan anak mereka. orang tua AdD memiliki tantangan yang besar dalam merawat dan memenuhi kebutuhan anak mereka. Secara ideal tanggung jawab orang tua ini membutuhan bantuan dan dukungan dari masyarakat untuk menciptakan suasana yang nyaman dan turut membantu agar AdD dapat berkembang dengan maksimal. Namun seringkali AdD mendapatkan perlakuan kekerasan maupun pengucilan dari masyarakat sekitar. Tujuan dari artikel ini adalah untuk mendeskripsikan mengenai pengetahuan masyaraat mengenai Hak AdD dan kesadaran mereka untuk bertindak memberikan dukungan pada orang tua dalam memenuhi kebutuhan AdD.

Hasil penelitian menunjukkan bahwa masyarakat tidak banyak mengetahui bagaimana cara untuk bersikap dan memperlakukan AdD dan orangtuanya. Selain itu masih ada orang tua AdD belum bisa memanfaatkan akses pelayanan kesehatan maupun pendidikan yang disediakan oleh pemerintah sebab mereka merasa malu untuk membawa anaknya bergaul dengan masyarakat lain. Sosialisasi dan penyuluhan mengenai penanganan AdD telah dilakukan oleh pihak kecamatan, namun masyarakat berpikir bahwa kegiatan ini hanya penting dihadiri oleh orang tua AdD. Hal ini lah yang menyebabkan banyak anggota masyarakat belum memiliki pengetahuan mengenai Hak AdD dan kesadaran untuk bertindak dalam membantu orang tua dalam memenuhi kebutuhan AdD. Pelaksanaan sosialisasi dan penyuluhan perlu dilakukan dari mulai unit pemerintahan terkecil di tingkat desa yaitu RT sehingga pengetahuan dan kesadaran masyarakat dapat meningkat.
\end{abstract}

Keywords: Anak dengan disabilitas, Kebutuhan anak, hak Anak

\section{ABSTRACT}

This article is the result of research from the Knowledge of the community regarding the Rights of Children with Disabilities (AdD) and Public Awareness to help AdD parents in regarding the fulfillment of their children's needs. AdD parents have a big challenge in caring for and meeting their children's needs. Ideally, the responsibilities of parents need help and support from the community to create a comfortable atmosphere and help make the ADD grow optimally. But often the AdD gets treatment of violence and exclusion from the surrounding community. The purpose of this article is to describe the community's knowledge of AdD Rights and their awareness to act to provide support to parents in meeting the needs of the AdD.

The results of the study show that the community does not know much about how to behave and treat the $A d D$ and their parents. In addition, there are still AdD parents who have not been able to take advantage of access to health and education services provided by the government because they feel embarrassed to bring their children to get along with other communities. Dissemination and counseling on handling ADD has been carried out by the sub-district, but the community thinks that this activity is 


\begin{tabular}{|c|c|c|c|c|}
\hline Share: Social Work Jurnal & VOLUME: 9 & NOMOR: 1 & HALAMAN: 66-74 & $\begin{array}{c}\text { ISSN:2339-0042 (p) } \\
\text { ISSN: 2528-1577 }(e) \\
\text { Doi: } 10.24198 / \text { share.v8i1.18100 }\end{array}$ \\
\hline
\end{tabular}

only important to be attended by AdD parents. This is what causes many community members not to have knowledge about AdD Rights and awareness to act in helping parents to meet the needs of AdD. Implementation of socialization and counseling needs to be carried out from the smallest government units at the village level, namely RT so that public knowledge and awareness can increase.

\section{Key words: Children with Disabilities, Child's need, Right of Child}

\section{PENDAHULUAN}

Tanggung jawab untuk memelihara anak dengan Disabilitas (selanjutnya disebut AdD) bukan hanya terletak pada orang tua anak namun juga pada lingkungan keluarga terdekat serta masyarakat di lingkungan yang lebih luas. Kondisi fisik dan mental AdD membuat mereka berada dalam posisi yang rawan untuk mendapat perlakuan tidak nyaman seperti mendapat ejekan, pengucilan, serta kekerasan fisik dari lingkungan sekitarnya. Dalam kondisi ini, orang tua yang memiliki AdD memainkan peranan yang sangat banyak seperti diungkapkan oleh Alper (1995: hal 261):" all member of the family of the child with disabilities play multiple roles. These roles include nurturing care giver, observer, team member, and decision maker, tutor, learner, counselor and advocate". Peran yang lakukan oleh orang tua sangat kompleks, oleh karena itu orang tua AdD membutuhkan dukungan dari lingkungan sekitarnya. Komunitas secara ideal seharusnya menjadi sistem sumber bagi orang tua agar dapat menghadapi tantangan dalam pemenuhan hak AdD secara lebih mudah.

Irwanto (2016) mengemukakan bahwa permasalahan yang dihadapi oleh AdD di Indonesia maupun orang tuanya adalah pengucilan dan stigma. Alih-alih mendapatkan perhatian maupun bantuan dari masyarakat sekitar, seringkali mereka mengalami pengucilan. Bahkan secara lebih jauh AdD mendapatkan perlakuan kekerasan atau "bully" dari lingkungan sekitarnya. Hal ini selaras dengan yang dikemukakan oleh Marchant (2001) bahwa AdD dan keluarganya sering terpinggirkan dan terpisahkan dari komunitas mereka dalam waktu bersenang-senang, mendapatkan akses pendidikan, mendapatkan kesempatan, dibandingkan dengan anak yang normal.

Tantangan bagi orang tua AdD diperburuk oleh ketersediaan dan akses terhadap layanan untuk memenuhi kebutuhan hidup dari anak mereka. Pusat Kajian Disabilitas Fisip Universitas Indonesia (2016) mengemukakan bahwa sulitnya akses terhadap layanan disebabkan oleh adanya stigma dari masyarakat sekitar terhadap AdD dan membuat keluarga merasa rendah diri untuk memanfaatkan layanan yang ada. Pemerintah memiliki peranan yang sangat penting dalam pelayanan terhadap AdD. Pemerintah Indonesia melalui Kementerian Sosial telah memiliki berbagai program layanan bagi penyandang disabilitas termasuk bagi AdD. Antara lain (1)Layanan bersifat institusional yaitu melalui Rehabilitasi di Panti atau Balai, (2) layanan non Institusional yaitu Unit Pelayanan Sosial Keliling (UPSK), pelatihan keterampilan bagi penyandang disabilitas (Loka Bina Karya), Rehabilitasi Berbasis Masyarakat, serta jaminan sosial keluarga yang memiliki anggota keluarga termasuk ke dalam kategori penyandang disabilitas melalui program Keluarga Harapan.

Pada beberapa Wilayah di Jawa Barat, hasil temuan ILO (2013) mengemukakan bahwa layanan bagi AdD masih minim, di antaranya layanan kesehatan dan layanan pendidikan khusus bagi AdD yang jaraknya jauh dari tempat tinggal sementara itu Lestari (2017) menyatakan bahwa masih banyak orang tua yang malu dan minder dengan kondisi anak mereka sehingga tidak mengizinkan anaknya untuk bersekolah. Kedua hasil penelitian tersebut mengemukakan bahwa tingkat ekonomi penduduk sebagian besar pada tingkat sedang dan rendah, sehingga orientasi lebih layanan terhadap AdD kalah dengan prioritas untuk pemenuhan kebutuhan untuk kelangsungan hidup keluarga. Hal tersebut diperkuat dengan stigma buruk dari masyrakat sehingga ayah dan ibu dari AdD yang merasa malu memiliki AdD dan tidak mengizinkan anaknya berbaur dengan lingkungan sekitar.

Alim (2014), dalam penelitiannya Kepedulian Masyarakat terhadap Anak Berkebutuhan Khusus di Lingkungan SLB N B 


\begin{tabular}{|c|c|c|c|c|}
\hline Share: Social Work Jurnal & VOLUME: 9 & NOMOR: 1 & HALAMAN: 66-74 & $\begin{array}{c}\text { ISSN:2339 -0042 (p) } \\
\text { ISSN: 2528-1577 (e) } \\
\text { Doi: } 10.24198 / \text { share.v8i1.18100 }\end{array}$ \\
\hline
\end{tabular}

Sumedang mengemukakan bahwa tanggapan masyarakat mengenai anak berkebutuhan khusus masih beragam, hal ini dilatar belakangi oleh perbedaan pekerjaan, pendidikan dan status sosial akan memberikan pemahaman serta kepedulian masyarakat terhadap suatu objek atau situasi tertentu akan berbeda-beda sesuai dengan pengetahuan atau pengalaman yang mereka dapatkan. Secara umum masyarakat masih berpikir bahwa saat bertemu dengan AdD tersebut mereka akan menjauhinya, namun demikian adapula masyarakat yang lebih memilih cuek dan merasa tidak peduli dengan keberadaan mereka, sehingga keluarga yang memiliki anak berkebutuhan khusus merasa malu untuk membawa mereka keluar rumah. Tanggapan Masyarakat yang masih memandang aneh mengenai keberadaan AdD terntu memberikan beban berat bagi orang tua AdD, sebab selain harus fokus untuk merawat dan memenuhi kebutuhan anak, orang tua memiliki perasaan tidak nyaman dengan lingkungan sekitar mereka.

Tim Nasional Percepatan Penanggulangan Kemiskinan (TNP2K) pada tahun 2011 mencatat lebih dari 12 ribu anak dengan disabilitas berada dalam keluarga miskin di Provinsi Jabar. Kurangnya kesadaran masyarakat, terutama keluarga, menjadi salah satu tantangan besar dalam menghilangkan stigma (cap buruk) dan diskriminasi kepada anak dengan disabilitas. Di perkotaan sekalipun, masih terdapat anak dengan disabilitas yang ditelantarkan oleh keluarganya. (sumber :https://www.republika.co.id/berita/nasional/da erah/15/04/10/nmklhy-12-ribu-anakdisabilitas-keluarga-miskin-ada-di-jabar)

Terdapat kurang lebih 3000 AdD di Kabupaten Bandung Barat, fenomena pengucilan dan stigma buruk bagi AdD dan Keluarga masih terjadi di wilayah ini. Akibatnya anak mengalami kesulitan dalam mendapatkan pemenuhan kebutuhannya seperti kebutuhan kasih sayang, pendidikan, pengakuan, yang seharusnya mereka dapatkan dari orang tua dan masyarakat. Sementara orang tua memiliki keterbatasan pengetahuan mengenai pengasuhan terhadap AdD, yang menyebabkan orang tua sering merasa frustasi. Kepedulian masyarakat terhadap AdD masih rendah, masyarakat masih memandang hanya keluarga yang terdekat yang memiliki tanggung jawab untuk peduli terhadap AdD.

Pengetahuan masyarakat mengenai mengenai hak AdD serta kesadaran untuk bersikap atas pengetahuan yang mereka miliki merupakan hal penting yang akan mendukung pemenuhan kebutuhan hidup AdD. Sebab jika masyarakat tidak memiliki pengetahuan mengenai hak dan kesadaran mengenai keberadaan AdD maka ketidakadilan, keterbatasan akses, serta pemenuhan kebutuhan AdD akan terhambat. Pengetahuan dan kesadaran ini akan mendorong terciptanya pemenuhan hak dasar AdD untuk menikmati kehidupan yang utuh dan layak, dalam kondisi yang menjamin martabat, meningkatkan diri kemandirian dan memfasilitasi partisipasi aktif AdD dalam masyarakat.

\section{METODE}

Penelitian dilakukan menggunakan pendekatan kualitatif dengan metode deskriptif untuk mendeskripsikan pengetahuan masyarakat mengenai hak AdD dan kesadaran masyarakat dalam memenuhi kebutuhan AdD. Penelitian dilakukan di Kabupaten Bandung Barat khususnya di kecamatan Padalarang. Pengambilan data dilakukan melalui analisis data sekunder, observasi non partisipatif, serta wawancara mendalam pada orang tua AdD, tokoh masyarakat di bidang pendidikan, kesehatan, serta pemerintahan yang ada. Jumlah Informan yang berhasil di wawancarai adalah sebanyak 23 orang yang terdiri dari tokoh masyarakat, orang tua yang memiliki anak AdD, serta warga yang tempat tinggalnya dekat dengan keluarga yang memiliki AdD.

\section{PEMBAHASAN}

\section{Pusataka: Anak dengan disabilitas, Hak Anak dan pemenuhan Kebutuhan anak}

Terminologi Anak dengan Disabilitas (AdD) mulai dikenal pada awal tahun 2010 di Indonesia terutama pada penggiat atau aktivis anak. Istilah lain yang dikenal oleh masyarakat untuk menyebut anak dengan keterbatasan fisik maupun mental adalah Anak berkebutuhan Khusus (ABK) dan anak Difabel, maupun Anak Penyandang Cacat.

Konvensi Hak-hak Anak United Nation Children's Found (UNICEF) menyebutkan 


\begin{tabular}{|c|c|c|c|c|}
\hline Share: Social Work Jurnal & VOLUME: 9 & NOMOR: 1 & HALAMAN: 66-74 & $\begin{array}{c}\text { ISSN:2339 -0042 (p) } \\
\text { ISSN: 2528-1577 (e) } \\
\text { Doi: } 10.24198 / \text { share.v8i1.18100 }\end{array}$ \\
\hline
\end{tabular}

bahwa "Anak adalah setiap orang yang berusia dibawah 18 tahun". Sementara itu Undangundang no 8 tahun 2016 menyebutkan bahwa disabilitas adalah "setiap orang yang mengalami keterbatasan fisik, intelektual, mental, dan/atau sensoris dalam jangka waktu lama dalam berinteraksi dengan lingkungan dapat mengalami hambatan dan kesulitan untuk berpartisipasi secara penuh dan efektif dengan warga negara lainnya berdasarkan kesamaan hak. Ragam penyandang disabilitas dapat dialami secara tunggal, ganda, atau multi dalam jangka waktu lama yang ditetapkan oleh tenaga medis sesuai dengan ketentuan peraturan perundang-undangan".

Secara konseptual, AdD memiliki definisi Anak disabilitas fisik adalah anak yang mengalami kelainan pada satu atau lebih organ tubuh tertentu, sehingga mengakibatkan gangguan pada fungsi tubuh. Akibat kelainan tersebut mereka mengalami hambatan dalam pergerakan tubuh (body movement), kemampuan melihat (visual ability), kemampuan mendengar (hearing) atau kemampuan bicara (speaking). (JICA, 2002). Sementara itu kerusakan struktur dan fungsi saraf juga dapat terjadi pada anak disabilitas fisik, seperti pada anak cerebral palsy sehingga perkembangan mentalnya tidak sesuai usia pertumbuhannya.

Setiap anak tidak terkecuali AdD mempunyai hak yang sama. Menurut Komnas Perlindungan Anak (2009), empat dasar hak yang harus didapatkan oleh anak antara lain:

1. Hak hidup lebih layak

AdD berhak atas kasih sayang orang tua, ASI eksklusif, akte kelahiran dan lain sebagainya. Setiap anak, tidak terkecuali anak dengan disabilitas berhak mendapatkan kehidupan yang layak.

2. Hak tumbuh dan berkembang

Hak untuk tumbuh dan berkembang ini antara lain pendidikan yang layak, istirahat, makan-makanan yang bergizi, belajar, bermain, dan lain-lain. Setiap anak, tidak terkecuali anak dengan disabilitas berhak untuk tumbuh dan berkembang, antara lain mendapatkan kebutuhan dasar yaitu makanan yang bergizi, mendapatkan pendidikan, mendapatkan rekreasi, dan lain-lain.

3. Hak perlindungan
Hak perlindungan mengacu pada keamanan anak dari kekerasan dalam rumah tangga, pelecehan seksual, tindak kriminal, pekerjaan layaknya orang dewasa, dan lain sebagainya. Setiap anak, tidak terkecuali anak dengan disabilitas mempunyai hak untuk mendapatkan perlindungan dari adanya kekerasan dan kriminalitas

4. Hak berpartisipasi

Secara lebih lengkap terdapat 10 Hak Anak menurut PBB dalam Konvensi Hak Anak 20 November 1989 antara lain :

1. Hak untuk bermain

2. Hak untuk mendapatkan pendidikan

3. Hak untuk mendapatkan perlindungan

4. Hak untuk mendapatkan nama (identitas)

5. Hak untuk mendapatkan status kebangsaan

6. Hak untuk mendapatkan makanan

7. Hak untuk mendapatkan akses kesehatan

8. Hak untuk mendapatkan Rekreasi

9. Hak untuk mendapatkan kesamaan

10. Hak untuk berperan dalam pembangunan

Berdasarkan hak-hak tersebut di atas, pemenuhan hak dan kebutuhan AdD tidak memiliki perbedaan dengan anak non AdD. AdD harus dipenuhi hak maupun kebutuhannya oleh orang dewasa yang ada di sekitarnya terutama dari orangtua AdD. Dengan lingkungan yang nyaman dan mendukung untuk tumbuh kembang secara optimal, antara lain pemberian kasih sayang, perhatian, dan pemenuhan kebutuhan kepada anak, anak dapat berfungsi secara optimal. Setiap anak berhak untuk menyampaikan pendapat, punya suara dalam musyawarah keluarga, punya hak berkeluh kesah, dan memilih pendidikan sesuai minat dan bakat, dan lain-lain. pemenuhan hak dan kebutuhan AdD secara optimal akan terwujud jika orang tua maupun lingkungan sekitarnya memiliki pengetahuan dan kesadaran mengenai hak yang dimiliki oleh anak tersebut.

Notoatmodjo (2003) mengemukakan bahwa pengetahuan adalah hasil penginderaan manusia terhadap suatu objek tertentu. 


\begin{tabular}{|c|c|c|c|c|}
\hline Share: Social Work Jurnal & VOLUME: 9 & NOMOR: 1 & HALAMAN: 66-74 & $\begin{array}{c}\text { ISSN:2339 -0042 (p) } \\
\text { ISSN: 2528-1577 (e) } \\
\text { Doi: } 10.24198 / \text { share.v8i1.18100 }\end{array}$ \\
\hline
\end{tabular}

Penginderaan ini melalui panca indera yang dimiliki manusia meliputi penglihatan, pendengaran, penciuman, rasa dan raba. Hasil dari penginderaan menghasilkan sebuah informasi yang dapat bersifat menetap dan mendorong tindak dari seseorang.

Dalam kata lain, pengetahuan merupakan berbagai gejala yang ditemui dan didapatkan oleh manusia melalui pengamatan akal. Pengetahuan akan muncul saat seseorang menggunakan akal budinya untuk mengenali benda atau suatu kejadian tertentu yang belum pernah dilihat atau dirasakan sebelumnya. Sehingga disebutkan pada awalnya manusia tidak memiliki pengetahuan setelah mengalami kejadian atau mengamati sebuah fenomena mereka menjadi memiliki pengetahuan. Dengan kata lain pengetahuan adalah informasi yang telah dikombinasikan dengan pemahaman dan potensi untuk bertindak.

Pengetahuan yang dimiliki oleh masyarakat mengenai AdD merupakan informasi yang dimiliki berdasarkan hasil pengamatan dan pengalaman. Pengetahuan mengenai AdD dimiliki oleh masyarakat jika mereka tidak melakukan pengamatan maupun mendapatkan pengalaman dari berbagai sumber antara lain pendidikan formal maupun informal. Namun demikian pengetahuan dapat dimiliki oleh masyarakat berdasarkan hasil pengamatan dari perilaku orang lain dalam memperlakukan AdD, sehingga perlakukan terhadap AdD yang berlaku di sebuah wilayah dapat merupakan contoh bertindak bagi keseluruhan masyarakat. Hal ini lah yang perlu digaris bawahi bahwa pengetahuan yang dimiliki akan mendorong masyarakat untuk memiliki kesadaran untuk bertindak atau berperilaku dalam upaya pemenuhan kebutuhannya.

\section{Hasil Lapangan}

Pengetahuan dan kesadaran mengenai hak AdD akan mendorong masyarakat yang tinggal di sekitar rumah AdD untuk memberikan support bagi perkembangan dan pemenuhan hak dan kebutuhannya. Secara ideal masyarakat harus memberikan perlakuan yang sama seperti terhadap anak yang normal serta memiliki kepedulian terhadap orang tua AdD, sebab orang tua AdD membutuhkan dukungan dalam menghadapi berbagai tantangan yang mereka hadapi.

Di Kecamatan Padalarang kasus anak dengan disabilitas dianggap sedikit tabu untuk dibicarakan. Pada awalnya Informan tidak terlalu terbuka mengenai bagaimana interaksi mereka dengan AdD sebab menurut mereka isu AdD termasuk pada ranah pribadi bagi keluarga yang memiliki AdD. Masyarakat merasa kuatir untuk sekedar menanyakan kabar mengenai kondisi AdD dari tetangga atau kerabat mereka akan menimbulkan ketersinggungan.

Pada awal tahun 1990 an di kabupaten Bandung Barat masih terjadi kasus penelantaran terhadap AdD sebab orangtua maupun masyarakat sekitar yang menganggap anak cacat itu mengganggu atau bahkan sebagai aib bagi keluarga. Keluarga cenderung menutupi dan menyembunyikan anak mereka tanpa diperbolehkan untuk bergaul dengan anak lain atau melihat dunia luar. Bahkan di Kecamatan Padalarang terdapat istilah: "anak kolong" atau artinya anak yang ditempatkan di kolong rumah panggung. Hal ini dilakukan oleh orang tua AdD pada masa itu agar anaknya tidak mengganggu masyarakat. Kejadian ini diketahui masyarakat sekitar namun cenderung didiamkan. Masyarakat setempat menganggap bahwa mengurus anak merupakan tanggung jawab orangtua, jika ikut terlibat mereka kuatir disebut ikut campur rumah tangga orang lain.

Pengetahuan masyarakat mengenai disabilitas maupun hak AdD masih minim disebabkan latar belakang pendidikan yang rendah. Sebenarnya pemerintah kecamatan telah melakukan sosialisasi mengenai apa itu AdD melalui pekerja sosial komunitas dan kader PKK. Namun masyarakat secara umum tidak begitu memperdulikan sosialisasi tersebut disebabkan aktivitas pekerjaan serta sibuk mengurus keluarga sendiri. Sehingga pada akhirnya sosialisasi dan penyuluhan hanya dihadiri oleh orang tua yang memiliki anak dengan disabilitas beserta beberapa orang kader. Meskipun kegiatan tersebut terbuka untuk umum, namun masyarakat biasanya memandang materi mengenai AdD tidak penting untuk mereka. Mereka enggan untuk meluangkan waktu hadir di kegiatan penyuluhan tersebut karena tidak memiliki anak atau anggota keluarga dengan disabilitas. 


\begin{tabular}{|c|c|c|c|c|}
\hline Share: Social Work Jurnal & VOLUME: 9 & NOMOR: 1 & HALAMAN: 66-74 & $\begin{array}{c}\text { ISSN:2339 -0042 (p) } \\
\text { ISSN: 2528-1577 (e) } \\
\text { Doi: } 10.24198 / \text { share.v8i1.18100 }\end{array}$ \\
\hline
\end{tabular}

Masyarakat masih berpikir bahwa pemenuhan kebutuhan dan hak AdD hanya wajib dilakukan oleh orang tuanya, bukan menjadi tanggung jawab dari masyarakat secara keseluruhan.

Pemahaman masyarakat yang tinggal di sekitar AdD mengenai isu disabilitas masih sangat terbatas pada terminology "cacat" dan "gila". Menurut mereka anak cacat yaitu ketika secara fisik dianggap tidak sama dengan anakanak lain. Sedangkan gila dikenal ketika anak tersebut mengalami hambatan perkembangan baik secara fisik maupun emosional. Hal ini menyebabkan masyarakat di sekitar tempat tinggal AdD bersikap tidak peduli dengan keberadaan mereka selama AdD tersebut tidak mengganggu anak-anak mereka. Hanya petugas puskesmas dan instansi pemerintah yang sudah mengenal tentang jenis-jenis disabilitas seperti, tuna wicara, tuna rungu, cacat mental, tuna grahita. Sementara selama ini mereka belum pernah mengetahui mengenai bagaimana memperlakukan atau menangani AdD dengan baik.

Kurangnya pengetahuan masyarakat mengenai hak AdD menyebabkan masyarakat belum tergerak untuk memahami mengenai pemenuhan kebutuhan AdD. Sebagai contoh salah seorang tetangga AdD cenderung bingung untuk bersikap dan berperilaku terhadap AdD dan orang tuanya. isu mengenai diabilitas masih belum menjadi milik masyarakat secara keseluruhan. Bahkan di antara beberapa orang tua dari AdD masih belum semua menyadari pentingnya mengikuti sosialisasi dan penyuluhan tentang pengasuhan bagi AdD. Hal ini disebabkan orang tua yang bekerja ataupun merasa malu untuk datang dan berkumpul dengan anggota masyarakat lain.

Rendahnya pengetahuan mengenai hak AdD merupakan sebuah gambaran bahwa masyarakat secara umum belum memahami apa yang harus dia lakukan dalam upaya memenuhi kebutuhan AdD. Bahkan beberapa informan orangtua mengutarakan kesulitan dalam berkomunikasi dengan anaknya yang tuna rungu. Hal ini menjadi hambatan dalam pemenuhan kebutuhan akan kasih sayang, sebab komunikasi antara anak dan orang tua baik secara verbal maupun non verbal tidak dapat berjalan dengan baik. Orang tua sangat mengharapkan ada pelatihan tentang cara komunikasi dengan anak dan mereka sangat membutuhkan pelatihan untuk terapi sederhana untuk anaknya. Sehingga proses pemenuhan kebutuhan anak mereka bisa terlaksana dengan baik. Pengetahuan orang tua AdD pun perlu untuk terus diasah dan ditingkatkan sehingga AdD dapat lebih terpenuhi kebutuhannya.

Terkait dengan Sosialiasasi, penyuluhan maupun pelatihan terkait dengan isu disabilitas selama ini telah dilakukan oleh pemerintah Kecamatan sesuai dengan perda Jawa Barat no 7 tahun 2013 mengenai Penyelenggaraan Perlindungan bagi Penyandang disabilitas. Penyuluhan dilakukan oleh pekerja Sosial kecamatan, kaden maupun bidan desa. Sosialisasi dan penyuluhan dilakukan dengan tujuan supaya masyarakat lebih memahami keberadaan AdD di lingkungan sekitar mereka. Namun kegiatan sosialiasi maupun penyuluhan tersebut masih bersifat ekslusif karena pihak pemerintah pun masih berpikir bahwa orangorang tertentu saja yang perlu diundang, seperti halnya orang tua AdD, dokter atau bidan desa, guru konseling di sekolah, pekerja sosial kecamatan, dan petugas layanan di puskesmas. Hal ini yang kemudian menyebabkan masih terjadi pengucilan, ejekan atau cemoohan terhadap AdD yang dilakukan oleh sesama anak maupun oleh orang dewasa yang tinggal di sekitarnya. Dengan demikian pemenuhan kebutuhan mendapatkan perlindungan dan rasa aman menjadi berkurang bagi AdD yang disebabkan ketidaktahuan cara bersikap dari orang yang berada dis ekitarnya.

Rendahnya pengetahuan ini kemudian menyebabkan rendahnya kesadaran orang tua untuk terlibat dalam kegiatan komunitas di tiap desa. Meskipun orang tua AdD ikut berpartisipasi sedangkan anak -anak mereka yang disabilitas tidak diikutkan kecuali pada acara - acara hiburan ada beberapa orangtua yang membawa anaknya. Namun kesadaran orang tua dalam mendorong pemenuhan anak untuk berpartisipasi dalam kegiatan kemasyarakatkan masih rendah karena kekhawatiran orang tua bahwa anaknya akan menjadi bahan olok-olok. Demikian pula dengan masyarakat sekitar atau tetangganya belum memiliki kesadaran untuk mengajak atau mendorong AdD untuk ikut terlibat dalam kegiatan kemasyarakatan seperti acara perayaan 


\begin{tabular}{|c|c|c|c|c|}
\hline Share: Social Work Jurnal & VOLUME: 9 & NOMOR: 1 & HALAMAN: 66-74 & $\begin{array}{c}\text { ISSN:2339-0042 (p) } \\
\text { ISSN: 2528-1577 }(e) \\
\text { Doi: } 10.24198 / \text { share.v8i1.18100 }\end{array}$ \\
\hline
\end{tabular}

Hari Kemerdekaan RI pada setiap tanggal 17 Agustus. Dengan demikian hak anak untuk bermain maupun berekreasi sesuai yang disepakati oleh PBB dalam Konvensi Hak Anak 1989 belum dapat terpenuhi bagi AdD di kecamatan Padalarang.

Sebenarnya masyarakat tidak berkeberatan untuk membantu keluarga yang memiliki AdD, namun bantuan tersebut sulit untuk diberikan sebab mereka tidak tahu harus bagaimana bersikap dan orang tua $\mathrm{AdD}$ cenderung tertutup. Kurangnya pengetahuan dan rendahnya kesadaran dari masyarakat termasuk orang tua AdD ini disebabkan oleh tingkat ekonomi yang dan latar belakang pendidikan yang rendah serta ketidaktahuan masyarakat mengenai hak AdD.

Dengan demikian pemenuhan kebutuhan atas perlindungan dan pengembangan diri bagi AdD belum diketahui secara komprehensif oleh masyarakat Kecamatan Padalarang secara umum. Masyarakat memahami bahwa mereka tidak boleh memberikan perlakuan buruk terhadap AdD, namun justru orangtua AdD yang biasanya cenderung protektif terhadap anak untuk tidak bergaul dengan teman-teman sebaya.

Perlakuan tidak adil terhadap AdD masih terjadi di Kecamatan Padalarang, sebab masyarakat masih meyakini bahwa kekerasan masih diperlukan untuk melakukan pendidikan terhadap AdD maupun terhadap anak normal. Sebab dalam pemahaman masyarakat terdapat perbedaan antara "melakukan kekerasan" dan "mendidik dengan kekerasan". Dalam pemahaman masyarakat menjadi hal yang lumrah untuk mendidik anak dengan memarahi atau menjewer. Tindakan child abuse juga sering dilakukan oleh orangtua anak sendiri seperti perkataan yang kasar, menampar, menyentil, hingga dipukul. Pemenuhan hak AdD untuk mendapatkan perlindungan justru dicederai oleh orang tua mereka sendiri sebab ketidaktahuan dan kurangnya pemahaman.

Kabupaten Bandung Barat memiliki sebuah forum Rehabilitas Berbasis Masyarakat (RBM) maupun forum khusus keluarga yang memiliki Anak dengan Disabilitas. Namun pada saat penelitian ini dilakukan, RBM baru baru sampai pada tahap pelatihan Kader. Kondisi ini menyebabkan belum ada keterbukaan antara pemerintah setiap keluarga dengan AdD cenderung tertutup satu sama lain, terutama pada keluarga yang tidak memiliki AdD. Perasaan sendirian menghadapi permasalahan kerap dirasakan oleh orangtua AdD, sebab seringkali mereka membutuhkan tenaga, fikiran, dan materi yang cukup besar dalam merawat Anak mereka.

Kurangnya pengetahuan orang tua dalam penanganan AdD ini menyebabkan permasalahan lain muncul dalam keluarga. Kekerasan terhadap anak kerap terjadi dalam keluarga baik terhadap AdD maupun anak yang lain yang memiliki kemampuan normal. Salah satu kasus yang terjadi pada keluarga yang memiliki AdD, adalah kekerasan yang dilakukan orangtua (pemukulan dan bentakan) terhadap anaknya yang non AdD. Hal ini terjadi orang tua orang tua merasa stress dalam menangani anak AdD sehingga anaknya yang lain (bukan AdD) menjadi tempat penyaluran kekesalan ibunya. Secara tidak disadari orang tua kemudian menjadi pelaku kekerasan terhadap anak mereka sendiri akibat stress dan tidak memiliki pengetahuan mengenai bagaimana cara untuk menangani anak dengan disabilitas.

Penanganan isu disabilitas di Kabupaten Bandung Barat masih terkendala dengan kurangnya koordinasi antara pemerintah Kecamatan dengan pemerintah desa. Dari hasil diskusi diakui bahwa untuk penanganan AdD, orang tua AdD justru lebih sering bersentuhan langsung dengan pihak Kecamatan, khususnya dengan Pekerja Sosial Kecamatan, tanpa melalui campur tangan desa sama sekali. Kegiatan pendataan, penginformasian yang terjadi belum berjalan sesuai alur yang semestinya. Pihak pemerintah Desa cenderung sulit untuk diajak berkoordinasi, dalam hal ini Pekerja Sosial Kecamatan di wilayah Kecamatan Padalarang ini sangat aktif dalam melakukan pendataan dan penjangkauan pada keluarga AdD. Bahkan saat proses pengambilan data ini berlangsung dilakukan rapat bersama desa-desa di Kecamatan Padalarang untuk mengumpulkan profil desa yang juga berisikan data data anak berkebutuhan khusus.

Pekerja Sosial Kecamatan Padalarang sudah sangat cepat tanggap, tetapi yang menjadi masalah adalah koordinasi dengan desa yang 


\begin{tabular}{|c|c|c|c|c|}
\hline Share: Social Work Jurnal & VOLUME: 9 & NOMOR: 1 & HALAMAN: 66-74 & $\begin{array}{c}\text { ISSN:2339-0042 (p) } \\
\text { ISSN: 2528-1577 }(e) \\
\text { Doi: } 10.24198 / \text { share.v8i1.18100 }\end{array}$ \\
\hline
\end{tabular}

sulit terjalin. Pihak desa yang seharusnya menjadi kepanjang tanganan pihak kecamatan justru sering tidak berperan serta dalam berbagai program. Banyak dari perangkat desa belum menangani dengan serius isu isu yang ada sehingga para relawan memilih untuk terjun langsung ke lapangan dan melakukan tindakan tanpa ada koordinasi dari desa.

Meskipun upaya pemerintah Kecamatan Padalarang belum optimal dalam menangani masalah AdD, PSM yang bertugas di Kecamatan Padalarang telah melakukan upaya pendataan terhadap AdD. Mereka menampung berbagai laporan dari warga dan juga sering melakukan kunjungan langsung ke rumahrumah warga yang memiliki permasalahan. Selain itu juga mereka sering mencari informasi sendiri dengan terjun ke lapangan langsung dan kemudian menghimpun data yang didapat untuk dilaporkan ke desa maupun Kecamatan. Pekerja Sosial di Kecamatan Padalarang juga aktif untuk mengumpulkan dan menggerakan kaderkader agar ikut serta dalam penanganan dan pelayanan terhadap AdD, sehingga hasilnya kini bisa dirasakan bahwa masyarakat juga mulai terbuka kepada mereka.

Pelayanan yang sudah berjalan selama ini adalah pendataan dan juga deteksi dini yang dilakukan oleh bidan. Pendeteksian dilakukan mulai dari anak sejak dini dan biasanya pada saat dilakukan kegiatan Posyandu. Selain deteksi dini pada anak, para kader posyandu maupun Pekerja Sosial Kecamatan juga memfasilitasi warga miskin yang hendak mengakses pelayanan dan bantuan, misalnya dengan pengurusan surat keterangan tidak mampu untuk keperluan membuat jamkesmas atau jamkesda. Dalam jaring pengamanan di bidang kesehatan Tidak ada perbedaan antara keluarga AdD dengan anak non disabilitas. Mereka sama-sama mendapatkan jaminan kesehatan yang berupa Jamkesmas maupun Jamkesda. Dari hasil diskusi, terlihat bahwa tidak sulit bagi masyarakat dalam mengurus pembuatan Jamkesmas maupun Jamkesda. Yang menjadi kendala adalah bahwa jamkesda memiliki batas tertentu dalam nominal pengobatan sedangkan untuk AdD biasanya tidak dapat diselesaikan dalam 1 kali proses pengobatan.
Dukungan pemerintah Kecamatan Padalarang terhadap AdD belum diikuti dengan layanan pendidikan yang bagi AdD. Di wilayah ini masih belum terdapat sekolah yang mau menerima AdD. Beberapa sudah menerima tapi hanya terbatas kepada anak yang anggota tubuhnya tidak lengkap saja (tuna daksa). Untuk mengakses SLB juga tidak mudah bagi anakanak disabilitas yang berada di Kecamatan Padalarang karena terbatasnya jumlah SLB tersebut. Terdapat juga sekolah yang sudah inklusif dan mau menerima anak disabilitas tetapi sekolah tersebut merupakan sekola swasta yang terkenal dengan biaya yang cukup tinggi untuk dapat bersekolah di sekolah tersebut.

Pengetahuan dan kesadaran masyarakat terhadap pemenuhan hak AdD ini sudah mulai berkembang dan dimiliki khususnya oleh orang tua AdD dan kader, hal ini dapat dilihat dalam 3 (tiga) tahun terakhir sudah tidak adanya kasus pemasungan bagi AdD. Namun isu tentang disabilitas, bagaimana perlakuan yang sesuai, serta pemenuhan hak bagi AdD seperti belum difahami oleh masyarakat secara umum. Hal ini menyebabkan pemenuhan kebutuhan anak untuk mendapatkan perlindungan dari kekerasan fisik maupun verbal belum dimiliki oleh masyarakat secara luas. Sementara itu lambat laun pemenuhan kebutuhan tumbuh kembang meliputi interaksi, pendidikan, rekreasi mulai difahami masyarakat dengan aktivitas PSM yang bergerak hingga ketingkat desa.

\section{PENUTUP}

Pengetahuan dan kesadaran masyarakat mengenai pemenuhan hak bagi AdD di Kecamatan Padalarang, masih terbatas pada pemerintah formal, kader, serta tokoh masyarakat yang memiliki pendidikan yang tinggi. Sementara pada masyarakat di sekitar tempat tinggal AdD mereka belum mengetahui bagaimana cara memperlakukan AdD dengan baik, sehingga masih terjadi ejekan maupun pengucilan terhadap AdD. Perlakuan tidak menyenangkan dan menghambat bagi pemenuhan hak AdD masih terjadi dengan orang tua sebagai pelaku kekerasan. Selain itu orang tua seringkali merasa malu jika mengajak 


\begin{tabular}{|c|c|c|c|c|}
\hline Share: Social Work Jurnal & VOLUME: 9 & NOMOR: 1 & HALAMAN: 66-74 & $\begin{array}{c}\text { ISSN:2339 -0042 (p) } \\
\text { ISSN: 2528-1577 (e) } \\
\text { Doi: } 10.24198 / \text { share.v8i1.18100 }\end{array}$ \\
\hline
\end{tabular}

anak mereka untuk bergaul dengan masyarakat secara luas.

Masyarakat Kecamatan Padalarang masih enggan untuk turut memberikan bantuan pada orang tua dalam memenuhi hak AdD sebab mereka tidak mengetahui bagaimana untuk bersikap sebab mereka kuatir sikap mereka justru akan menyinggung perasaan orang tua. Belum munculnya kesadaran untuk membantu orangtua dalam memenuhi hak AdD ini disebabkan oleh tingkat pengetahuan mengenai AdD masih sangat terbatas. terlebih dengan adanya pandangan masyarakat mengenai stigma buruk yang masih melekat pada AdD dengan masih adanya sebutan "cacat" atau "gila". Selama ini orang tua mendapatkan bantuan untuk memenuhi kebutuhan AdD melalui posyandu dan Pekerja Sosial Kecamatan. Perlakuan tidak adil, penelantaran, pengacuhan terhadap AdD yang masih terjadi di kecamatan Padalarang masyarakat umum belum mengetahui bahwa anak dengan disabilitas memiliki hak yang sama dengan anak lain yang dilahirkan normal. Sebab selama ini kegiatan sosialisasi dan penyuluhan yang dilakukan oleh pemerintah ataupun kader hanya dihadiri oleh orangtua AdD. Oleh karena itu dibutuhkan upaya untuk meningkatkan kesadaran dan pengetahuan bagi mereka mengenai layanan dan dukungan bagi AdD, sehingga masyarakat dapat turut terlibat dalam pemenuhan kebutuhannya.

Pengetahuan dan masyarakat mengenai hak AdD ini dapat ditingkatkan melalui upaya sosialisasi yang tidak hanya diperuntukkan bagi orang tua AdD. Kegiatan ini dapat dilakukan mulai level Kecamatan, Desa, hingga maupun di unit lingkungan terkecil seperti RT. RT perlu memiliki skema atau alur kerja untuk memberikan pelayanan atau pertolongan dasar pada AdD. Keberadaan Rehabilitasi Berbasis Masyarakat di Kabupaten Bandung Barat perlu diajak kerjasama oleh Pekerja Sosial Kecamatan dan kader. Diharapkan masyarakat yang tinggal di sekitar AdD memiliki kepedulian dalam pemenuhan kebutuhan AdD dan berkontribusi dalam menyediakan lingkungan yang nyaman bagi tumbuh dan kembang AdD.

\section{Referensi:}

Alim, Raden Ajeng Sri Rizjil (2014), Kepedulian Masyarakat terhadap Anak Berkebutuhan Khusus di Lingkungan SLB $\quad N \quad B \quad$ Sumedang, Tesis S1, Universitas Pendidikan Indonesia.

Alper, PJ Schloss, CN Schloss (1995) Families of children with disabilities in elementary and middle school: Advocacy models and strategies, Exceptional Children Journal, Vol. 2 Issue 3, p.261-270)

Dyah Wieka. 2005. Retardasi mental, Tingkat penerimaan. Jakarta: Fakultas Unika Atma Jaya

Eta Yuni Lestari, Slamet Sumarto, Noorochmat Isdaryanto (2017), Pemenuhan Hak Bagi Penyandang Disabilitas Di Kabupaten Semarang Melalui Implementasi Convention On The Rights Of Persons With Disabillities (Cprd) Dalam Bidang Pendidikan, Jurnal Integralistik, Vol. 28 No. 1, Universitas Negeri Semarang.

Irwanto, Irwanto \& Kasim, Eva \& Fransiska, Asmin \& Lusli, Mimi \& Okta, Siradj. (2016). Analisis Situasi Penyandang Disabilitas di Indonesia: Sebuah Desk Review. Pusat kajian Disabilitas Fisip Universitas Indonesia

Marchant R. (2001), Working with disabled children. In: Foley P., Roche J., Tucker S., editors. Children in Society: Contemporary Theory, Policy and Practice. Basingstoke: Palgrave in association with Open University Press.

Meloni, F., Federici, S., \& Dennis, J. L. (2015). Parents' education shapes, but does not originate, the disability representations of their children. PLoS One, 10(6) doi:http://dx.doi.org/10.1371/journal.po ne. 0128876

Notoatmodjo, S. 2003. Pendidikan dan Perilaku Kesehatan. PT. Rineka Cipta. Jakarta 